\title{
Effects of supplemental irrigation on yield, water use efficiency and nitrogen use efficiency of potato grown in mollic Andosols
}

\author{
Felix Satognon ${ }^{*}$ (D), Seth F. O. Owido and Joyce J. LeleiAbstract
}

\begin{abstract}
Background: Low soil fertility and reduced seasonal rainfall contribute to low potato (Solanum tuberosum L.) yield in Kenya. Nitrogen ( $\mathrm{N}$ ) deficiency is the major problem facing by the smallholder farmers of Kenya due to lack of fallow. Hence an introduction of supplemental irrigation with an adequate application of this nutrient could increase potato yield. The objective of this study was to determine the effects of supplemental irrigation and $\mathrm{N}$-fertilisation on potato tuber yield, water use efficiency (WUE) and nitrogen use efficiency (NUE). The experiment was conducted in Nakuru County, Kenya for two seasons. The experimental soils are classified as mollic Andosols. The treatments comprised two irrigation treatments of full supplemental irrigation (FI) and rainfed production (RF) and four $\mathrm{N}$ levels of four $\mathrm{N}$ levels of 0 (N0), 60 (N1), 90 (N2) and $130 \mathrm{~kg} \mathrm{~N} / \mathrm{ha}(\mathrm{N} 3)$.
\end{abstract}

Results: The results showed that total tuber yield, marketable tuber yield and NUE were significantly $(P<0.001)$ affected by irrigation $\times \mathrm{N}$-fertilisation while WUE was only affected $(\mathrm{P}<0.001)$ by $\mathrm{N}$-fertilisation. The highest total tuber yield, 58.28 tonnes/hectare (t/ha), was recorded under FI combined with N3. Treatment Fl significantly increased marketable tuber yield by approximately $125.58 \%$ in all $\mathrm{N}$ treatments compared to RF. The highest NUE of potato ( $236.44 \mathrm{~kg} / \mathrm{kg}$ of N) was obtained under FI combined with N3 but not significantly different from the NUE of potato obtained under FI with N2. N-fertilisation N3 produced the highest WUE of $14.24 \mathrm{~kg} / \mathrm{m}^{3}$. Significant correlation was obtained between tuber yield and number of tubers/plant $(r=0.75, \mathrm{P}<0.001)$, NUE $(r=0.95, \mathrm{P}<0.001)$ and WUE $(r=0.72, \mathrm{P}<0.001)$.

Conclusion: High potato yield and marketable tuber yield can be achieved in mollic Andosols when water deficits of the growing season are eliminated with supplemental irrigation and an application of $130 \mathrm{~kg} \mathrm{~N} / \mathrm{ha}$.

Keywords: N-fertilisation, NUE, Potato, Supplemental irrigation, WUE, Yield

\section{Background}

Potato (Solanum tuberosum L.) is the second most important staple food and cash crop in Kenya, after maize (Zea mays) (Muthoni et al. 2017; Waaswa and Satognon 2020). Its production is predominantly rainfed (Muthoni et al. 2021). Population pressure and the need to produce more to satisfy the demand for potato have consequently led to encroachment of farming into marginal lands, forest reserves and non-traditional

\footnotetext{
*Correspondence: felixsatognon@gmail.com

Department of Crops, Horticulture and Soils, Faculty of Agriculture,

Egerton University, P. O. Box 536-20115, Egerton, Njoro, Kenya
}

potato-producing areas (Muthoni et al. 2021). In Kenya, the area under production increased from 135,000 ha in 2008 to 217, 315 ha in 2018. Despite the increased area under production, a low yield of $8.6 \mathrm{t} / \mathrm{ha}$ was obtained in 2018, registering a decline of $60 \%$ from 2008 (FAOSTAT 2020; Mburu et al. 2020; Mcewan et al. 2021). Previous research attributed the low potato yield to the reduction of seasonal rainfall in the potato-growing areas of Kenya from 737 to $126 \mathrm{~mm}$ (Waaswa et al. 2021). Drought or dry periods between rainfall seasons and increased temperatures, which lead to high crop evapotranspiration, are experienced in $70-80 \%$ of the smallholder farms in Kenya (Bryan et al. 2013; Kimathi et al. 2021; Muthoni 
et al. 2017; Taiy et al. 2017). Soils in most potato-growing areas in Kenya are classified as mollic Andosols. These soils become dry a few days after a rainfall event due to their high infiltration rates. Potato is sensitive to water deficit and slight water stress causes a reduction in leaf number and size, canopy radiation interception and photosynthesis, which consequently affects the tuber number/plant, size and yield ( $\mathrm{Li}$ et al. 2016). Supplemental irrigation is a perfect technique to cope with the effect of climate variability in Kenya. Supplemental irrigation is when water is supplied to essentially rainfed crops during the period when precipitation fails to uniformly provide sufficient amounts of water required by the crop to fully produce its potential yield. This method helps to maintain the soil moisture at a high level and eliminate the water deficit in the plant root zone. Research conducted in China showed that $55 \mathrm{~mm}$ of supplemental irrigation could increase potato yield up to 50.8\% (Tang et al. 2018).

Nitrogen deficiency is another major problem facing by the smallholder farmers of potato in Kenya due to a lack of fallow (Satognon et al. 2021). Nitrogen deficiency is manifested by reduced growth and tuber yield in terms of tuber number/plant and size (Koch et al. 2020). It is well known that soil water affects nutrient transport to the root surface in the water flux created by transpiration (mass flow) (Smethurst 2004) and high water uptake by plant roots considerably enhances root $\mathrm{N}$ acquisition by mass flow (Mcmurtrie and Näsholm 2018). Water stress reduces $\mathrm{N}$ uptake as a result of the decrease in water uptake and transpiration rate (Koch et al. 2020). Hence a suppression of water stress in the root zone during the growing season can improve $\mathrm{N}$ uptake by potato crops. The objective of this study was to determine the effects of supplemental irrigation and $\mathrm{N}$-fertilisation rates on tuber yield, NUE and WUE of potato grown in mollic Andosols in Kenya.

\section{Materials and methods}

\section{Experimental site description}

A two-season field experiment was conducted between July 2020 and January 2021 at the experimental farm of Agro-Science Park of Egerton University in Nakuru County, Kenya. The experimental site is located in agro-ecological zone III of Kenya $\left(0.3031^{\circ} \mathrm{S}, 36.0800^{\circ} \mathrm{E}\right)$ at an altitude of $2670 \mathrm{~m}$ above sea level. Climatic factors including precipitation (Fig. 1), maximum and minimum temperature and humidity of the growing seasons (Table 1) were obtained from the weather station of Egerton University located $1 \mathrm{~km}$ away from the experimental site. Maize, wheat (Triticum aestivum), beans (Phaseolus vulgaris) and potato are the most common crops grown in the study area. The soils at the experimental site are well-drained, dark reddish clays, slightly acidic and contain medium levels of organic carbon and low levels of phosphorus, and they are classified as mollic Andosols (Jaetzold et al. 2007).

\section{Experimental procedure Determination of chemical properties of experimental soils}

To determine the initial soil properties, soil samples were randomly taken from six locations at two different depths $(0-0.15 \mathrm{~m}$ and $0.15-0.45 \mathrm{~m})$ since the potato root zone falls in 0 and $0.4 \mathrm{~m}$. The collected samples were mixed to obtain one composite sample per depth. The composite samples were air-dried at room temperature $\left(22-25^{\circ} \mathrm{C}\right)$ for a week, crushed and sieved through a $2-\mathrm{mm}$ sieve. The baseline soil chemical analyses were performed at the soil testing laboratories of Kenya Agricultural and Livestock Research Organisation (KALRO), Nairobi. Soil pH was measured in a 1:1 (w/v) water extract. The Kjeldahl digestion method was used to analyse the total $\mathrm{N}$ content of the composite samples (Okalebo et al. 2002). In this method, the $\mathrm{N}$ is initially converted to ammonia using metal-catalysed acid digestion (Motsara and Roy 2008). Soil elements such as phosphorus $(\mathrm{P})$, potassium $(\mathrm{K})$, calcium $(\mathrm{Ca})$, magnesium $(\mathrm{Mg})$, manganese $(\mathrm{Mn})$ and sodium $(\mathrm{Na})$ were extracted using the Mehlich double acid method. In this method elements such as $\mathrm{Na}$ and $\mathrm{K}$ were determined with a flame photometer while $\mathrm{Ca}, \mathrm{Mg}$ and $\mathrm{Mn}$ were measured using atomic absorption spectrophotometer (AAS). P was determined spectrophotometrically. Total organic carbon was analyzed using the colourimetric method (Anderson and Ingram 1993). Exchangeable acidity was measured at $\mathrm{pH}<5.5$ (Okalebo et al. 2002). Available iron (Fe), zinc (Zn) and copper $(\mathrm{Cu})$ were extracted in a 1:10 $(\mathrm{w} / \mathrm{v})$ ratio with $0.1 \mathrm{M} \mathrm{HCL}$ followed by AAS readings. For the quality control of the analyses, samples were analysed with the reference soil sample (with known values). Samples were also duplicated during the analyses. The initial chemical soil properties are shown in Table 2.

\section{Determination of physical properties of experimental soil}

To determine the physical properties of the experimental soils, soil texture with the percentage of each primary soil (sand, silt and clay) was determined using the hydrometer method (Bouyoucos 1962). Soil bulk density ( $\rho b)$ of samples collected at different depths with core rings was determined using the gravimetric method followed by the oven drying method (Blake 1965). Field capacity (FC) was assessed by subjecting the composite samples to pF2.5 followed by the oven drying method (at $105{ }^{\circ} \mathrm{C}$ for $24 \mathrm{~h}$ ) (Aschonitis et al. 2013). Permanent wilting point (PWP) was measured by subjecting the samples to 


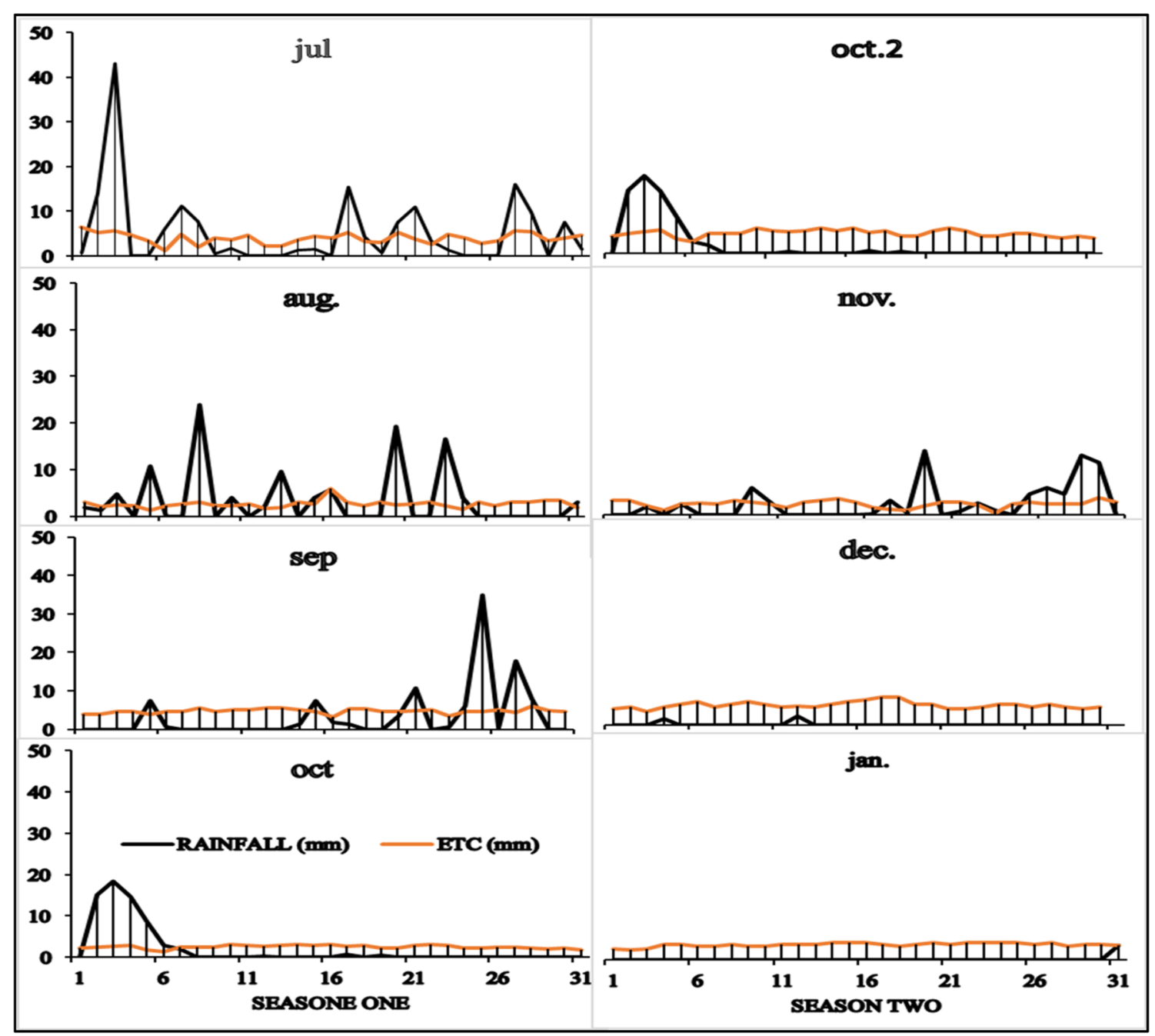

Fig. 1 Daily precipitation and $E T_{c}$ of the growing seasons

Table. 1 Meteorological data from weather station of Egerton University

\begin{tabular}{|c|c|c|c|c|c|c|c|}
\hline Parameters & Jul & Aug & Sep & Oct & Nov & Dec & Jan \\
\hline Average of maximum temperature $\left({ }^{\circ} \mathrm{C}\right)$ & 23.2 & 23.8 & 24.1 & 25.2 & 23.4 & 27.2 & 26.1 \\
\hline Average of minimum temperature $\left({ }^{\circ} \mathrm{C}\right)$ & 10.5 & 10.7 & 9.5 & 10.1 & 10.2 & 9.9 & 10.0 \\
\hline Average of humidity (\%) & 49.0 & 48.0 & 51.0 & 49.0 & 49.0 & 53.0 & 57.0 \\
\hline
\end{tabular}

a pressure of pF4.2 followed by the drying oven method. Available water (AW) was then computed by subtracting PWP from FC using Eq. 82 of FAO 56 (Allen et al. 1998).

$$
A W=1000\left(\theta_{F C}-\theta_{W P}\right) Z r,
$$

where; $\mathrm{AW}=$ total available soil water in the plant root zone depth $\left(\mathrm{m}^{3}\right), \theta_{\mathrm{FC}}=$ water content at field capacity $\left(\mathrm{m}^{3} / \mathrm{m}^{3}\right), \theta_{\mathrm{WP}}=$ water content at wilting point $\left(\mathrm{m}^{3} / \mathrm{m}^{3}\right)$, and $Z_{r}=$ rooting depth $(\mathrm{m})$.

The readily available water (RAW) which is the fraction of AW that a crop can deplete from the root zone without experiencing water stress was estimated using Eq. 83 of FAO (Allen et al. 1998). 
Table. 2 Soil chemical analyses of the experimental soils

\begin{tabular}{lllllll}
\hline Soil depth $(\mathbf{m})$ & $\mathbf{0 - 0 . 1 5}$ & & & $\mathbf{0 . 1 5 - 0 . 4 5}$ \\
\cline { 2 - 3 } \cline { 6 - 7 } Soil parameters & Value & Class & & Value & Class \\
\hline Soil pH & 5.43 & Medium acid & & 5.46 & Medium acid \\
Exch. acidity meq\% & 0.20 & Adequate & & 0.21 & Adequate \\
Total nitrogen (N) \% & 0.16 & Low & & 0.14 & Low \\
Total Org. carbon \% & 1.69 & Moderate & & 1.61 & Moderate \\
P ppm & 21 & Low & & 19.1 & Low \\
K meq\% & 1.14 & Adequate & & 1.11 & Adequate \\
Ca meq\% & 5.6 & Adequate & & 5.4 & Adequate \\
Mg meq\% & 1.61 & Adequate & & 1.43 & Adequate \\
Mn meq\% & 1.37 & Adequate & & 1.25 & Adequate \\
Cu ppm & 1.80 & Adequate & & 1.71 & Adequate \\
Fe ppm & 12.2 & Adequate & & 12.2 & Adequate \\
Zn ppm & 2.45 & Low & & 2.42 & Low \\
Na meq\% & 0.18 & Adequate & & 0.17 & Adequate \\
\hline
\end{tabular}

$$
R A W=p A W
$$

where; RAW = readily available soil water in the plant root zone $(\mathrm{mm})$ and $\mathrm{p}=$ average fraction of AW that can be extracted from the root zone before water stress (reduction in $\mathrm{ET}_{\mathrm{c}}$ ) occurs. Its values range from 0 to 1 for various crops. The average fraction of potato is 0.35 . This value was taken from table 83 of FAO 56 (Allen et al. 1998). The physical soil properties of the experimental site are shown in Table 3.

\section{Water analysis for its suitability for irrigation}

To check the water suitability for irrigation, an aliquot of water was analysed at KALRO, Nairobi. The $\mathrm{pH}$ and electrical conductivity (EC) were measured with a $\mathrm{pH}$-meter. $\mathrm{Na}$ and $\mathrm{K}$ concentrations were measured with a flame photometer while $\mathrm{Ca}$ and $\mathrm{Mg}$ were determined using AAS. The chloride concentration of the water was determined by titrating an aliquot of water with silver nitrate and potassium chromate while carbonates were analysed as bicarbonates by titrating an aliquot of water with hydrochloric acid and phenolphthalein. The sulphate content of the sample was analysed using the turbidmetric method. The sodium absorption ratio was estimated using $\mathrm{Na}, \mathrm{Ca}$ and
Table. 4 Composition of irrigation water used

\begin{tabular}{ll}
\hline Parameters & Values \\
\hline $\mathrm{pH}$ & 8.09 \\
Conductivity (EC) mS/cm & 0.27 \\
Na meq\% & 0.37 \\
K meq\% & 0.12 \\
Ca meq\% & 0.04 \\
Mg meq\% & 0.05 \\
Carbonates meq\% & $\mathrm{ND}^{\mathrm{a}}$ \\
Bicarbonates meq\% & 0.75 \\
Chlorides meq\% & 1.92 \\
Sulphates meq\% & 49.9 \\
Sodium adsorption ratio & 1.74 \\
\hline
\end{tabular}

${ }^{\mathrm{a} N D \text { not detected }}$

Mg concentrations. The irrigation water used had a medium salinity level and high sulphate (Table 4). This indicated that the quality of water used for this study was suitable for irrigation. This interpretation was based on the USDA classification of irrigation water (Bauder et al. 2011; Scherer et al. 1996; Wilcox 1955). The soil of the experimental site was permeable with adequate drainage.

\section{Experimental design and treatments}

Before the experiment setup, the land was ploughed at $0.3 \mathrm{~m}$ depth after which plots were prepared by raising the soils. The treatments comprised two irrigation treatments of full supplemental irrigation (FI) and rainfed production (RF) and four $\mathrm{N}$ levels of 0 (N0), 60 (N1), 90 (N2) and $130 \mathrm{~kg} \mathrm{~N} / \mathrm{ha}(\mathrm{N} 3)$. Full supplemental irrigation (FI) was supplied using the drip irrigation method. Lateral driplines with $1.6 \mathrm{Lh}^{-1}$ at $100 \mathrm{kPa}$ inline drippers spaced at $30 \mathrm{~cm}$ were placed for each row. All plots received the same irrigation amount during the first two weeks to encourage crop establishment. The drip irrigation was then atomized in terms of minutes for FI plots after the two first weeks to deliver the calculated quantity of water based on daily crop evapotranspiration collected from the weather station of Egerton University. For FI treatment, irrigation was applied after the rain once $40 \%$ of soil available water was depleted. Soil available water was monitored using a time domain reflectometry

Table. 3 Physical properties of the experimental soils

\begin{tabular}{|c|c|c|c|c|c|c|c|c|c|}
\hline \multirow[t]{2}{*}{ Depth (m) } & \multicolumn{4}{|c|}{ Soil texture } & \multicolumn{4}{|c|}{ Moisture retention \% } & \multirow{2}{*}{$\begin{array}{l}\text { Bulk } \\
\text { density } \\
\left(\mathrm{g} / \mathrm{cm}^{3}\right)\end{array}$} \\
\hline & Sand \% & Silt \% & Clay \% & Class & FC & PWP & AW & RAW & \\
\hline $0.00-0.15$ & 63.7 & 26.2 & 10.1 & $\mathrm{SL}$ & 19.9 & 12.3 & 7.6 & 2.66 & 1.26 \\
\hline $0.15-0.45$ & 57.6 & 30.2 & 12.2 & $S L$ & 20.3 & 11.8 & 8.5 & 2.98 & 1.34 \\
\hline
\end{tabular}

$S L=$ Sandy Loam 


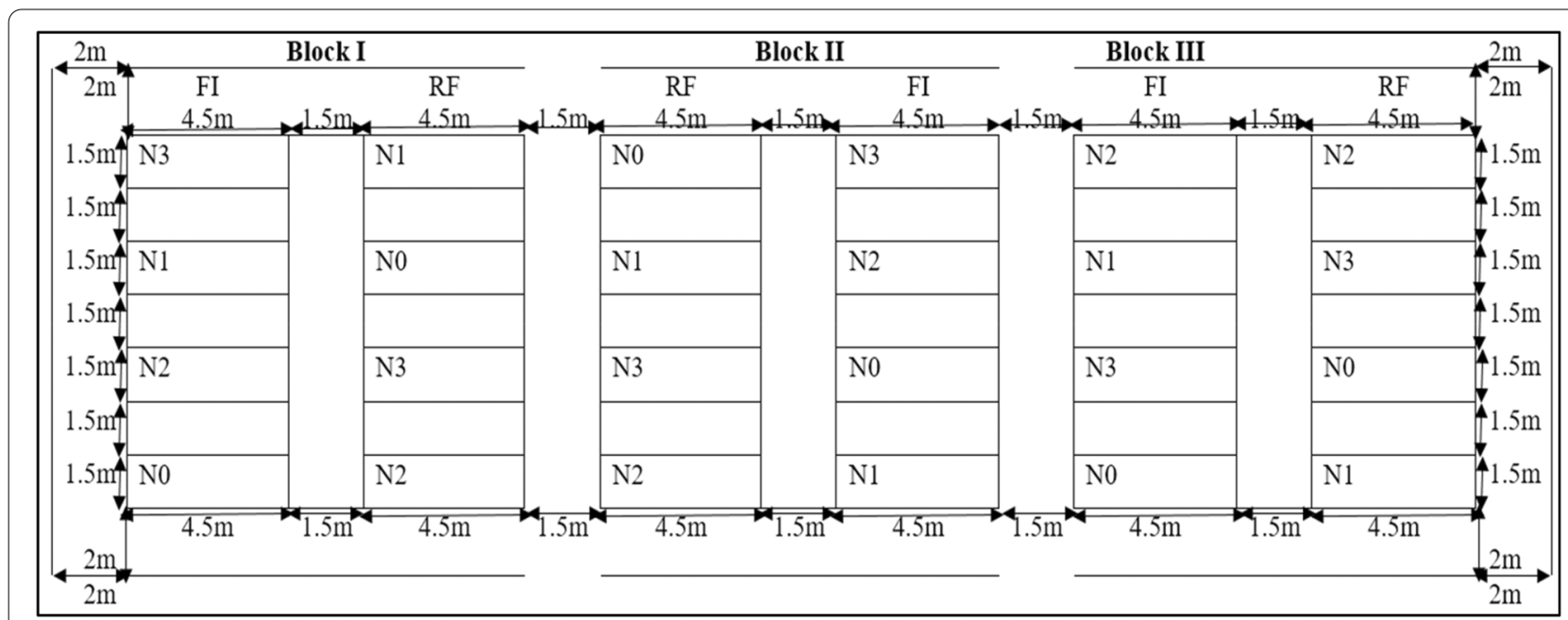

Fig. 2 Field layout

(TDR) moisture meter. All the $\mathrm{N}$-fertilisation treatments were split applied at $10(40 \%), 30(40 \%)$ and $50(20 \%)$ days after planting. Urea fertiliser was used as a source of $\mathrm{N}$.

A split-plot in a randomised complete block design was used (Fig. 2). Irrigation and $\mathrm{N}$ treatments were randomly assigned to the main plots and subplots, respectively. This is because irrigation required a large plot. Each treatment was replicated in three different blocks. The different blocks, main plots and subplots were separated by a $1.5 \mathrm{~m}$ buffer. Each experimental plot measured $7.5 \mathrm{~m}^{2}(5 \mathrm{~m} \times 1.5 \mathrm{~m})$ and $0.4 \mathrm{~m}$ depth. Each plot received 20 apical rooted cuttings of Shangi potato variety. They were planted at a spacing of $0.3 \mathrm{~m}$ and $0.70 \mathrm{~m}$ between plants and rows, respectively in a set of five rows. This gave a density of 47,617 plants/ha. Apical rooted cuttings were planted on 7 Jul. 2020 and 26 Oct. 2020 and tubers were manually harvested from the six plants in the middle rows of each subplot on 8 Oct. 2020 and 20 Jan. 2021, respectively. During planting, $90 \mathrm{~kg} / \mathrm{ha}$ of potassium sulphate (SOP) and $50 \mathrm{~kg} / \mathrm{ha}$ of triple superphosphate (TSP) fertilisers were added to each plot based on the universal recommendations of the area. Ridomil Gold MZ 68 WG $(1 \mathrm{~kg} / \mathrm{ha})$ combined with mancozeb $(1 \mathrm{~kg} / \mathrm{ha})$ fungicides were used to control the prevailing diseases especially the early and late blight diseases whereas VOLTAGE 5EC
(350 ml/ha) was used to control potato pests. Plots were manually weeded using a hand hoe and earthing up was manually done one month after planting.

\section{Crop water requirements}

Reference crop evapotranspiration $\left(\mathrm{ET}_{0}\right)$ was estimated based on daily data collected from the weather station of Egerton University using Penman-Monteith's (Allen et al. 1998; Jensen and Allen 2016).

$$
E T_{0}=\frac{\Delta(R n-G)+\rho_{a} c_{p}\left(\frac{e s-e a}{r a}\right)}{\Delta+\gamma\left(1+\frac{r s}{r a}\right)},
$$

where; $E T o=$ reference crop evapotranspiration, $\Delta=$ slope of vapor saturation pressure, $\mathrm{Rn}=$ net radiation, $\mathrm{G}=$ soil heat flux; $\rho_{a}=$ mean air density at the constant air pressure, $\mathrm{cp}=$ specific heat of the air, es ea $=$ vapour pressure deficit, $\gamma=$ psychrometric constant, $\mathrm{rs}=$ surface resistance and $\mathrm{ra}=$ aerodynamic resistance.

The actual crop evapotranspiration $\left(\mathrm{ET}_{\mathrm{c}}\right)$ was computed as the product of $\mathrm{ET}_{0}$ and the crop coefficient $\left(\mathrm{K}_{\mathrm{c}}\right)$.

$$
E T_{C}=K_{C} \times E T_{0} .
$$

The crop coefficient at different crop stages was calculated using the formulae 59, 62 and 65 of FAO (Allen

\begin{tabular}{|c|c|c|c|c|c|c|c|c|}
\hline \multirow[t]{2}{*}{ Months } & \multicolumn{4}{|c|}{ Season 1} & \multicolumn{4}{|c|}{ Season 2} \\
\hline & Jul & Aug & Sep & Oct & Oct & Nov & Dec & Jan \\
\hline $\mathrm{K}_{\mathrm{c}}$ & 1.14 & 0.75 & 1.12 & 0.63 & 1.18 & 0.78 & 1.14 & 0.65 \\
\hline $\mathrm{ET}_{0}(\mathrm{~mm})$ & 3.49 & 3.57 & 4.2 & 4.3 & 3.08 & 3.08 & 4.32 & 4.5 \\
\hline $\mathrm{ET}_{\mathrm{c}}(\mathrm{mm})$ & 4.63 & 4.32 & 5.32 & 4.93 & 4.26 & 3.86 & 5.46 & 5.15 \\
\hline
\end{tabular}

Table. 5 Monthly average of $K_{c^{\prime}} E T_{0}$ and $E T_{C}$ 
et al. 1998). The average values of Kc at different crop stages were 1.14 and 1.18 for the initial stage, 0.75 and 0.78 for the growth stage, 1.12 and 1.14 for the middle stage and 0.63 and 0.65 for the maturation stage for seasons one and two, respectively (Table 5). The equivalence period of different stages of potato corresponded to 25 , 30, 30 and 30 days for initial, growth, middle and tuber maturity stages.

The cumulative actual crop evapotranspiration (ETa) was computed over the growing season using a soil water balance equation (Steele et al. 1997; Jensen and Allen 2016).

$$
E T a=P+I \pm \Delta s-R-D,
$$

where; $\mathrm{P}=$ amount of precipitation throughout the potato-growing season, I=total amount of additional irrigation supplied during the growing season of potato $(\mathrm{mm}), \Delta \mathrm{S}=$ change in soil water content in the root zone during the growing season of potato $(\mathrm{mm}), \mathrm{R}=$ runoff loss $(\mathrm{mm})$ and $\mathrm{D}=$ loss due to deep drainage during the growth period ( $\mathrm{mm})$. $\mathrm{R}$ is ignored since the slope of the experimental site is relatively small with adequate soil infiltration and irrigation was supplied through drip irrigation. Loss due to deep drainage (D) was expected to occur when rainfall surpassed the soil water deficit (which was estimated as field capacity minus soil water content before a rain) in the root zone before precipitation. Irrigation never surpassed the soil water deficit level and thus, was considered to cause no loss due to deep drainage.

\section{Yield components}

Plant height, number of branches/plant, biomass, tuber number/plant, total tuber yield and marketable yield were collected as yield components on six plants from the middle rows of each subplot. The harvest index (HI) was expressed as the percentage of tuber yield in the total biomass at harvest (aboveground biomass plus tuber yield at harvest).

$$
H I(\%)=\frac{\text { Tuber Yield }\left(\frac{t}{h a}\right)}{\text { Total biomass at harvest }\left(\frac{t}{h a}\right)} \times 100 .
$$

\section{Water use efficiency and irrigation water use efficiency}

Water use efficiency (WUE) and irrigation water use efficiency (IWUE) were computed using the following equations (Erdem et al. 2006).

$$
\text { WUE }\left(\frac{\mathrm{kg}}{\mathrm{m}^{3}}\right)=\frac{\text { Total tuber Yield }\left(\frac{\mathrm{kg}}{\mathrm{ha}}\right)}{\operatorname{ETa}\left(\mathrm{m}^{3}\right)},
$$

$$
\operatorname{IWUE}\left(\frac{\mathrm{kg}}{\mathrm{m}^{3}}\right)=\frac{T Y I\left(\frac{\mathrm{kg}}{\mathrm{ha}}\right)-\operatorname{TYNI}\left(\frac{\mathrm{kg}}{\mathrm{ha}}\right)}{I\left(\mathrm{~m}^{3}\right)},
$$

where; TYI =total tuber yield of an irrigated plot, TYNI $=$ total tuber yield in of a non-irrigated plot and $\mathrm{I}=$ amount of irrigation supplied during the growing season of potato.

\section{Nitrogen use efficiency}

Nitrogen use efficiency (NUE) was computed using the following formula (Leal Filho et al. 2015).

$$
\operatorname{NUE}\left(\frac{k g}{k g}\right)=\frac{T y f p\left(\frac{k g}{h a}\right)-T y u f p\left(\frac{k g}{h a}\right)}{\text { Quantity of N applied }\left(\frac{k g}{h a}\right)},
$$

where Tyfp $=$ total tuber yield of a fertilised plot and Tyufp $=$ total tuber yield of an unfertilised plot.

\section{Data analysis}

Before analysis, the Shapiro Wilk test at 0.05 was conducted using $\mathrm{R}$ software (version 3.6.3) to test the normality of the data. For any data that was not normally distributed, fitting data transformation was performed. Analysis of variance (ANOVA) was also run using the same software. The least significant difference (LSD) test was used to separate the treatment means at 0.05 . Regression analyses were carried out at 0.05 to determine total tuber yield, WUE and NUE responses to $\mathrm{N}$ levels in mollic Andosols. Pearson correlation coefficient was carried out to test the significance of the relationship between tuber number/plant, WUE and NUE as well as total tuber yield. During the analysis, outlier data were identified using the control chart technique (Bakar et al. 2006) and any outlier data and not due to the treatment effect was deleted from the model and replaced by the nearest after confirming data entry error.

\section{Results and discussion}

\section{Crop water requirements}

During the first two weeks, 6.4 and $4.2 \mathrm{~mm}$ of water were supplied at the beginning of the first and the second seasons, respectively to encourage plant root establishment. The cumulative actual crop evapotranspiration $\left(E_{\mathrm{a}}\right)$ was 268.09 and $237.7 \mathrm{~mm}$ for RF and 359.47 and $381.89 \mathrm{~mm}$ for FI during the first and the second growing seasons, respectively. This showed that the crop water requirement was higher during the second season. This agreed with the previous studies that reported that $\mathrm{ET}_{\mathrm{a}}$ varied from 350 to $800 \mathrm{~mm}$ for various climates and environments (Adavi et al. 2018; Afzaal et al. 2020; Ati et al. 2010; Ati et al. 2012; Djaman et al. 2021; Ierna and 
Mauromicale 2018; Meligy et al. 2020; Nowacki 2018; Paredes et al. 2018). The amount of supplemental irrigation water applied was 91.38 and $144.19 \mathrm{~mm}$ for seasons one and two, respectively. This indicated a reduction in seasonal rainfall patterns due to low and erratic rainfall and high temperatures recorded during the second season. Muthoni et al. (2017) and Waaswa et al. (2021) reported a significant reduction in in-season rainfall followed by an uneven distribution of rainfall in Nakuru County, Kenya. This demonstrated the need for supplemental irrigation in the potato growing area of Nakuru county.

\section{Plant growth}

The effects of supplemental irrigation and $\mathrm{N}$-fertilisation on plant height and number of branches/plant are presented in Tables 6 and 7. The results showed that plant height and number of branches/plant of potato were not significantly affected by supplemental irrigation and the interaction effects of the two factors $(P>0.05)$. The average plant height during the two growing seasons in FI was higher than that in RF but did not differ significantly and this is in line with the previous research of Darabad (2014). However, many studies reported that potato crop height increases with an increase in the amount of irrigation water applied (Farrag et al. 2016; Metwaly and El-Shatoury 2017; Zhang et al. 2017). This difference in result can be attributed to the potato variety used in this study. However, a significant increase in plant height and number of branches/plant was observed as the amount of applied $\mathrm{N}$ increased $(\mathrm{P}<0.001)$. The highest plant height, $76.82 \mathrm{~cm}$, was recorded under N3. This increase of plant height with $\mathrm{N}$ dosage was also reported in previous research (Godebo and Belay 2020; Setu and Mitiku 2020; Tolessa et al. 2017). Sebnie et al. (2021) indicated that an application of mineral $\mathrm{N}$ fertiliser increased potato plant height compared to unfertilised plots.
Table. 7 Means separation of plant height, number of branches per plant and $\mathrm{HI}(\%)$

\begin{tabular}{|c|c|c|c|}
\hline & Plant height $(\mathrm{cm})$ & $\begin{array}{l}\text { Number of } \\
\text { branches/plant }\end{array}$ & HI (\%) \\
\hline \multicolumn{4}{|c|}{ Irrigation effect } \\
\hline $\mathrm{Fl}$ & 72.58 & 17 & 56.29 \\
\hline RF & 63.85 & 16 & 45.41 \\
\hline LSD & ns & ns & ns \\
\hline \multicolumn{4}{|c|}{ Nitrogen effect } \\
\hline N3 & $76.82 \mathrm{a}$ & $19 a$ & $54.69 a$ \\
\hline N2 & $69.35 b$ & $18 \mathrm{a}$ & $51.69 a b$ \\
\hline N1 & $67.36 b$ & $17 a$ & $49.12 b$ \\
\hline NO & $59.35 c$ & $14 b$ & $47.91 b$ \\
\hline LSD & 5.51 & 2.27 & 5.29 \\
\hline
\end{tabular}

ns not significant, alpha $=0.05$. The same letters within the same column indicate that there is no significant difference while different letters within the same column indicate there is a significant difference at 0.05

\section{Yield components}

The effects of supplemental irrigation and $\mathrm{N}$-fertilisation on yield components (tuber number/plant, total tuber yield, marketable yield and $\mathrm{HI}$ ) during the growing seasons are presented in Tables 6 and 7. The results indicated that irrigation, $\mathrm{N}$-fertilisation and irrigation $\times \mathrm{N}$-fertilisation exhibited a significant effect on tuber number/plant, total tuber yield and marketable yield of potato. Conversely, HI was only significantly affected by $\mathrm{N}$-fertilisation $(\mathrm{P}<0.001)$. The FI significantly increased tuber number/plant, tuber yield and marketable yield compared to RF, regardless of $\mathrm{N}$-fertilisation. For different irrigation treatments, the tuber number/ plant, total tuber yield and marketable yield ranged from 16 to $20,20.86$ to $44.11 \mathrm{t} / \mathrm{h}$, and 15.23 to $38.83 \mathrm{t} / \mathrm{ha}$, respectively. The tuber yield and marketable yield were higher during the second growing season. This increase in potato yield in the second season can be attributed to the high $\mathrm{ET}_{\mathrm{a}}$ recorded during the season. This is in line

Table. 6 Mean squares plant height, branch number/plant, tuber number/plant, yield, HI and marketable yield

\begin{tabular}{|c|c|c|c|c|c|c|c|}
\hline Source of variation & Df & Plant height & $\begin{array}{l}\text { Number of } \\
\text { branches/plant }\end{array}$ & Tuber number/plant & Total tuber yield & Marketable yield & $\mathrm{HI}$ \\
\hline Season & 1 & 226.03 & 455.53 & 107.97 & 42.84 & 131.50 & 268.94 \\
\hline Replicate (season) & 4 & 140.23 & 41.74 & 10.04 & 11.08 & 4.45 & 36.49 \\
\hline Irrigation & 1 & 914.73 & 6.89 & $225.37^{*}$ & $5172.76^{*}$ & $4942.84^{*}$ & 1422.01 \\
\hline $\begin{array}{l}\text { Season } \times \text { irrigation } \\
\text { (main plot error) }\end{array}$ & 1 & 349.27 & 6.40 & 2.36 & 74.12 & 33.05 & 96.84 \\
\hline Nitrogen & 3 & $618.75^{* * *}$ & $44.85^{* *}$ & $134.62^{* * *}$ & $1005.90^{* * *}$ & $993.62^{* * *}$ & $108.54^{*}$ \\
\hline Irrigation $\times$ nitrogen & 3 & 54.47 & 17.83 & $23.72^{* *}$ & $249.89^{* * *}$ & $200.94^{* * *}$ & 49.90 \\
\hline Error & 34 & 44.12 & 7.51 & 4.11 & 9.50 & 6.33 & $40.56^{*}$ \\
\hline CV & & 9.73 & 16.02 & 12.10 & 9.77 & 0.97 & 12.55 \\
\hline$R^{2}$ & & 0.73 & 0.76 & 0.85 & 0.97 & 9.60 & 0.63 \\
\hline
\end{tabular}

$\mathrm{HI}=$ Harvest Index, ${ }^{\prime * * * \prime \prime},{ }^{* * \prime}$ and ${ }^{\prime * \prime}$ are significance codes at $0.001,0.01$ and 0.05 , respectively 
with the previous research which reported that potato is very susceptible or sensitive to water stress compared to many other crops and full irrigation without water deficit throughout the potato cycle always leads to high yield (Darabad 2014; Mattar et al. 2021). Tuber initiation to maturity growth period forms the critical water requirement period where water deficits negatively affect potato productivity (Ahmadi et al. 2010; Salter and Goode 1967; Sasani et al. 2006). Begum et al. (2018) found that supplemental irrigation is very important for potato in the areas with a high drought frequency due to the high yield of potato in a short time and if shortage of readily available water in the soil is eliminated it is possible to achieve high and stable potato yield of 40-50 t/ha or more. Previous studies found an increase in tuber number/plant and marketable potato yield of irrigated potato compared to rain-fed production (Abu El-Fotoh et al. 2019; Djaman et al. 2021; Waqas et al. 2021). Djaman et al. (2021) also reported the highest tuber number/plant under full irrigation.

The tuber number/plant, tuber yield and marketable yield across $\mathrm{N}$-fertilisation varied from 13 to 23 , 22.75 to $45.06 \mathrm{t} / \mathrm{ha}$, and 16.12 to $39.84 \mathrm{t} / \mathrm{ha}$, respectively. The maximum tuber number/plant, tuber yield and marketable yield were observed with N3. Earlier works found that potato yield, regardless of irrigation, statistically increases with an increase in $\mathrm{N}$ rate up to $280 \mathrm{~kg} \mathrm{~N} /$ ha, then tend to increase faintly as $\mathrm{N}$ dosage increases further (Badr et al. 2012; Ospina et al. 2014; Shunka et al. 2017). Further research needs to be conducted to determine the optimal nitrogen level for potato production in mollic Andosols since this study did not find out the point at which an increase in $\mathrm{N}$ dosage might lead to a decrease in potato yield.

For irrigation $\times \mathrm{N}$-fertilisation effects, the highest tuber number/plant, 27, was obtained in FI with N3 treatment during the first season while the lowest value, 11, was found under RF with N0 during the second growing season (Fig. 3a, b). A significant increase in the total yield and marketable yield of all $\mathrm{N}$ treatments under FI compared to RF was also observed. Besides, the maximum total tuber yield, $62.12 \mathrm{t} / \mathrm{ha}$, and marketable yield, 55.79 $\mathrm{t} / \mathrm{ha}$, were found in FI with N3 during the second season whereas the smallest total tuber yield, $15.21 \mathrm{t} / \mathrm{ha}$, and marketable yield, $9.99 \mathrm{t} / \mathrm{ha}$, were found under RF with N0 during the second season and the first season, respectively (Fig. 3c-f). It was also found that FI enhanced marketable tuber yield by $129.84,94.63,151.21$ and $126.63 \%$

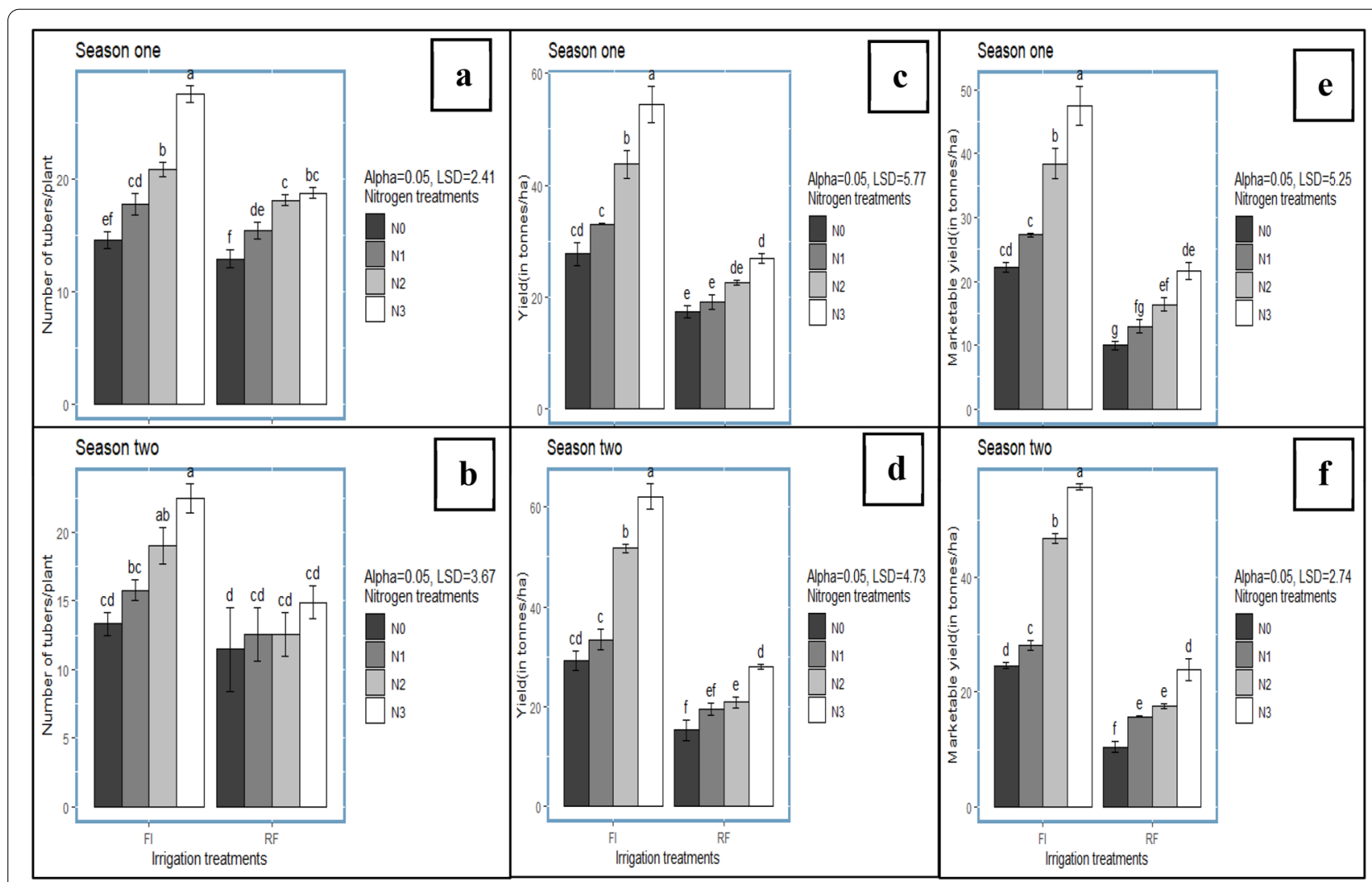

Fig. 3 Means separation of tuber number per plant, total tuber yield and marketable tuber yield of different growing seasons. Different letters indicate significant difference 
for N0, N1, N2 and N3, respectively compared to rain-fed $\mathrm{N}$-fertilisation. A significant effect of irrigation $\times \mathrm{N}$-fertilisation on tuber yield was reported by Badr et al. (2012) and Tolessa (2019).

An increment of $\mathrm{HI}$ with $\mathrm{N}$ level was found with the maximum value of HI, 54.69\%, recorded in N3. However, the HI obtained with N3 did not differ significantly from the HI observed with N2. It was also found that supplemental irrigation did not affect HI. This disagreed with the early studies that reported a significant effect of irrigation for $\mathrm{HI}$ of potato with a reduction in $\mathrm{HI}$ as water stress becomes more severe (Ruttanaprasert et al. 2016; Sobhani and Hamidi 2015). This could be explained by the fact that the water deficit under RF was not so severe to affect $\mathrm{HI}$ during the growing seasons. To achieve an optimum marketable yield of potato grown on mollic Andosols of Kenya, supplemental irrigation with a high N rate of $130 \mathrm{~kg} \mathrm{~N} / \mathrm{ha}$ is required.

\section{Water use efficiency (WUE) and irrigation water use efficiency (IWUE)}

Data collected on potato WUE and IWUE for all treatments are presented in Table 8. It was found that irrigation and irrigation $\times \mathrm{N}$-fertilisation did not interact with WUE. However, N-fertilisation statistically increased the WUE of potato. N-fertilisation N3 produced higher potato WUE $\left(14.24 \mathrm{~kg} / \mathrm{m}^{3}\right)$ followed by N2 $(11.69 \mathrm{~kg} / \mathrm{m} 3)$, N1 $\left(9.64 \mathrm{~kg} / \mathrm{m}^{3}\right)$ and N0 $\left(7.47 \mathrm{~kg} / \mathrm{m}^{3}\right)$ (Fig. $4 \mathrm{a}$, b). Previous studies found an increase in potato WUE with an increase in N rate (Badr et al. 2012; Tolessa 2019). IWUE indicated how the additional applied water was used by the crop in different $\mathrm{N}$-treatments. It was observed that $\mathrm{N}$-fertilisation considerably $(\mathrm{P}<0.001)$ interacted with

Table. 8 Mean squares of WUE and IWUE

\begin{tabular}{lrrlrc}
\hline $\begin{array}{l}\text { Source of } \\
\text { variation }\end{array}$ & Df & WUE & $\begin{array}{l}\text { Source of } \\
\text { variation }\end{array}$ & Df & IWUE \\
\hline Season & 1 & 23.41 & Season & 1 & 100.21 \\
Replicate (season) & 4 & 4.36 & Replicate & 2 & 2.42 \\
$\quad$ Irrigation & 1 & 48.72 & Nitrogen & 3 & $386.72^{* * *}$ \\
$\quad \begin{array}{l}\text { Season } \times \text { irriga- } \\
\quad \text { tion (main plot }\end{array}$ & 1 & 40.04 & Error & 17 & 17.18 \\
$\quad$ error) & & & & & \\
$\quad$ Nitrogen & 3 & $100.20^{* * *}$ & CV & & 23.08 \\
Irrigation $\times$ nitro- & 3 & 2.16 & $\mathrm{R}^{2}$ & & 0.82 \\
$\quad$ gen & & & & & \\
Error & 34 & 1.45 & & & \\
CV & & 11.22 & & & \\
$\mathrm{R}^{2}$ & & 0.90 & & & \\
\hline
\end{tabular}

$* * *$ is a significance code at 0.001 potato IWUE in mollic Andosols. IWUE obtained with $\mathrm{N}$-fertilisation $\mathrm{N} 3$ and $\mathrm{N} 2$ were high but did not differ from each other. The lowermost IWUE, $10.10 \mathrm{~kg} / \mathrm{m}^{3}$, was recorded with N0 (Fig. 4c, d). This indicated that the additional water applied was more significantly used by the crop when applying N3 and N2 than when applying $\mathrm{N} 1$ and N0.

\section{Nitrogen use efficiency (NUE)}

Irrigation, $\mathrm{N}$-fertilisation and irrigation $\times \mathrm{N}$-fertilisation exhibited a significant effect on NUE (Table 9). The maximum potato NUE, $197.22 \mathrm{~kg} / \mathrm{N}$ of $\mathrm{kg}$, was observed under FI. It was observed that the NUE of potato increased as the NUE of potato increased as the $\mathrm{N}$ level increased, with the maximum NUE obtained with N3, but it was not significantly different from potato NUE found with N2. The smallest NUE was obtained with N1. This is in line with the study of Badr et al. (2012). On the contrary, Banerjee et al. (2015) found that NUE decreased with an increase in $\mathrm{N}$ rate. For irrigation $\times \mathrm{N}$-fertilisation effects for NUE, it was observed a significant increase of potato NUE under FI during the two seasons compared to RF with the maximum NUE, $236.44 \mathrm{~kg} / \mathrm{N}$ of $\mathrm{kg}$, obtained under FI with N3 but not significantly different from the NUE of potato obtained under FI with N2 (Fig. 5a, b). This implied that for an improvement of NUE in potato grown in mollic Andosols, the amount of water and $\mathrm{N}$ dosage should be applied at their optimum levels. The optimum level of NUE in mollic Andosols can be achieved with $90 \mathrm{~kg} \mathrm{~N} / \mathrm{ha}$ since the NUE obtained with $130 \mathrm{~kg} \mathrm{~N} /$ ha did not differ from NUE recorded with $90 \mathrm{~kg} \mathrm{~N} / \mathrm{ha}$.

\section{Relationship between potato yield, WUE, NUE and N-rate under different irrigation treatments}

The production functions of tuber yield, WUE and NUE were evaluated in different irrigation treatments to show their responses to $\mathrm{N}$ level in mollic Andosols (Figs. 6, 7, 8). As expected, the relationships between tuber yield, WUE and NUE and N applied were linear (all F-values were significant at $\mathrm{P}<0.05$ ). The regression equations and determination coefficients between $\mathrm{N}$-fertilisation and tuber yield obtained were the following.

$$
\begin{aligned}
F I: Y & =0.2368 X+25.343, R^{2}=0.90 \text { and } \\
R F: Y & =0.0835 X+15.313, R^{2}=0.92 .
\end{aligned}
$$

These equations indicated that total potato tuber yield increased by about 236 and $83 \mathrm{~kg} / \mathrm{ha}$ for each $\mathrm{kg}$ of $\mathrm{N}$ applied under FI and RF, respectively. This showed that an increase in a unit of $\mathrm{N}$ greatly increased total potato tuber yield under FI compared to RF. The following 


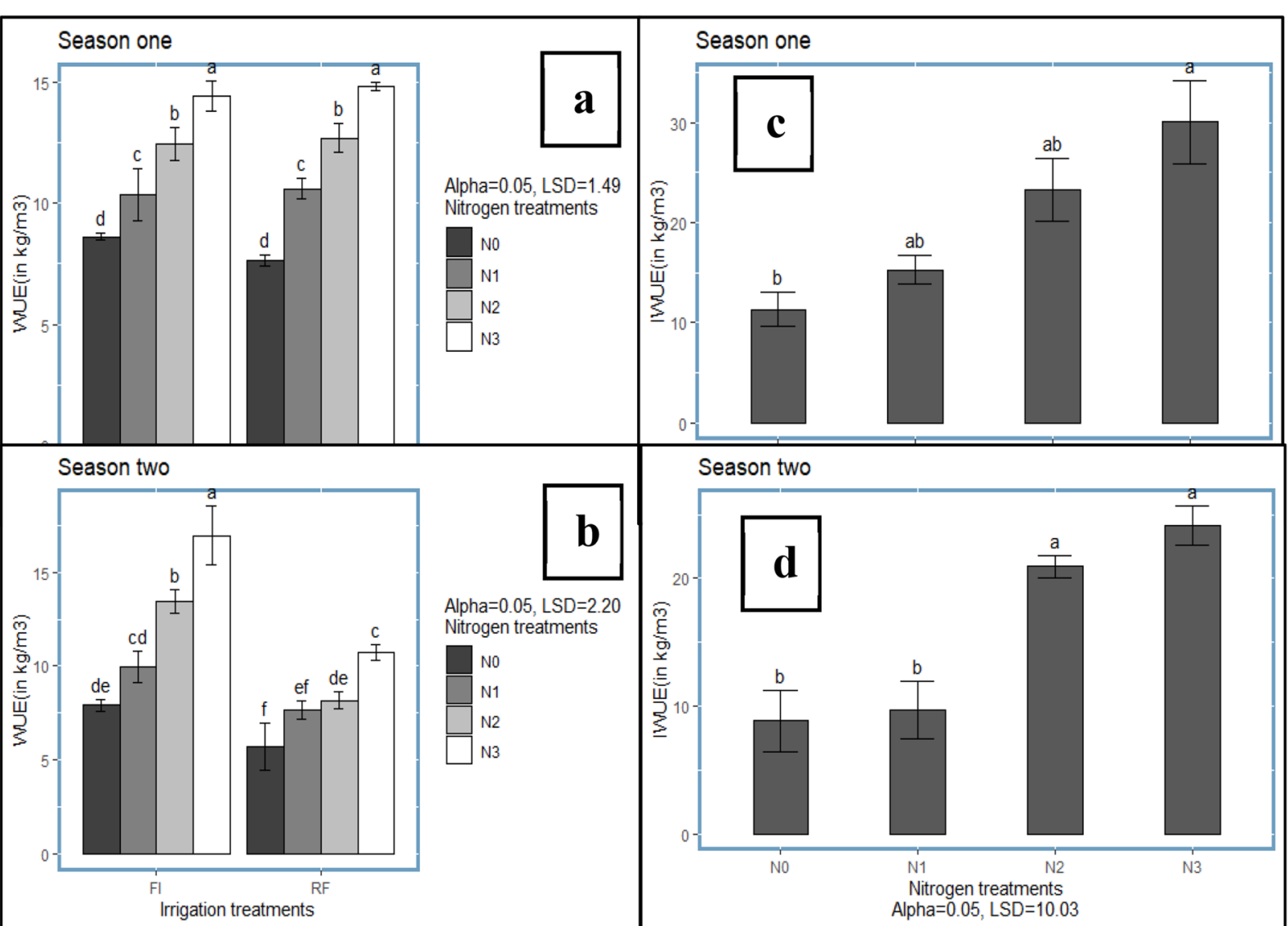

Fig. 4 Means separation of WUE and IWUE of different growing seasons. Different letters indicated significant difference

regression equations and determination coefficients were obtained between WUE and N-fertilisation.

$$
\begin{aligned}
F I: Y & =0.0578 X+7.7192, R^{2}=0.95 \text { and } \\
R F: Y & =0.0464 X+6.5086, R^{2}=0.99 .
\end{aligned}
$$

Table. 9 Mean squares of NUE

\begin{tabular}{lcc}
\hline Source of variation & Df & NUE \\
\hline Season & 1 & 5709.06 \\
Replicate (season) & 4 & 752.66 \\
Irrigation & 1 & $139,578.21^{*}$ \\
Season $\times$ irrigation (main plot error) & 1 & 604.58 \\
Nitrogen & 2 & $17,466.54^{* * *}$ \\
Nitrogen $\times$ irrigation & 2 & $6650.21^{* * *}$ \\
Error & 24 & 388.83 \\
CV & & 14.61 \\
$\mathrm{R}^{2}$ & & 0.95 \\
\hline
\end{tabular}

This indicated that an increment of each $\mathrm{kg}$ of $\mathrm{N}$ applied respectively in FI and RF increased the WUE of potato by approximately 0.057 and $0.04 \mathrm{~kg} / \mathrm{m}^{3}$. The highest slope of the regression between WUE vs $\mathrm{N}$-fertilisation corresponded to FI. Between NUE and N-fertilisation, the following equations and determination coefficients were also performed.

$$
\begin{aligned}
F I: Y & =1.4931 X+57.868, R^{2}=0.73 \text { and } \\
R F: Y & =0.4753 X+28.325, R^{2}=0.99 .
\end{aligned}
$$

The slopes of this equation showed that an increase of each $\mathrm{kg}$ of $\mathrm{N}$ applied enhanced the NUE of potato by approximately 1.49 and $0.47 \mathrm{~kg} / \mathrm{kg}$ of $\mathrm{N}$ under FI and RF, respectively. These results demonstrated the importance of supplemental irrigation in the growing area for a high NUE of potato. It was found that a significant positive correlation existed between tuber yield and both NUE $(r=0.95, \mathrm{P}<0.001)$ and WUE $(r=0.72, \mathrm{P}<0.001)$ (Fig. 9). The strong positive

$* * * * *$ and $*$ are significance codes at $0.001,0.01$ and 0.05 , respectively 

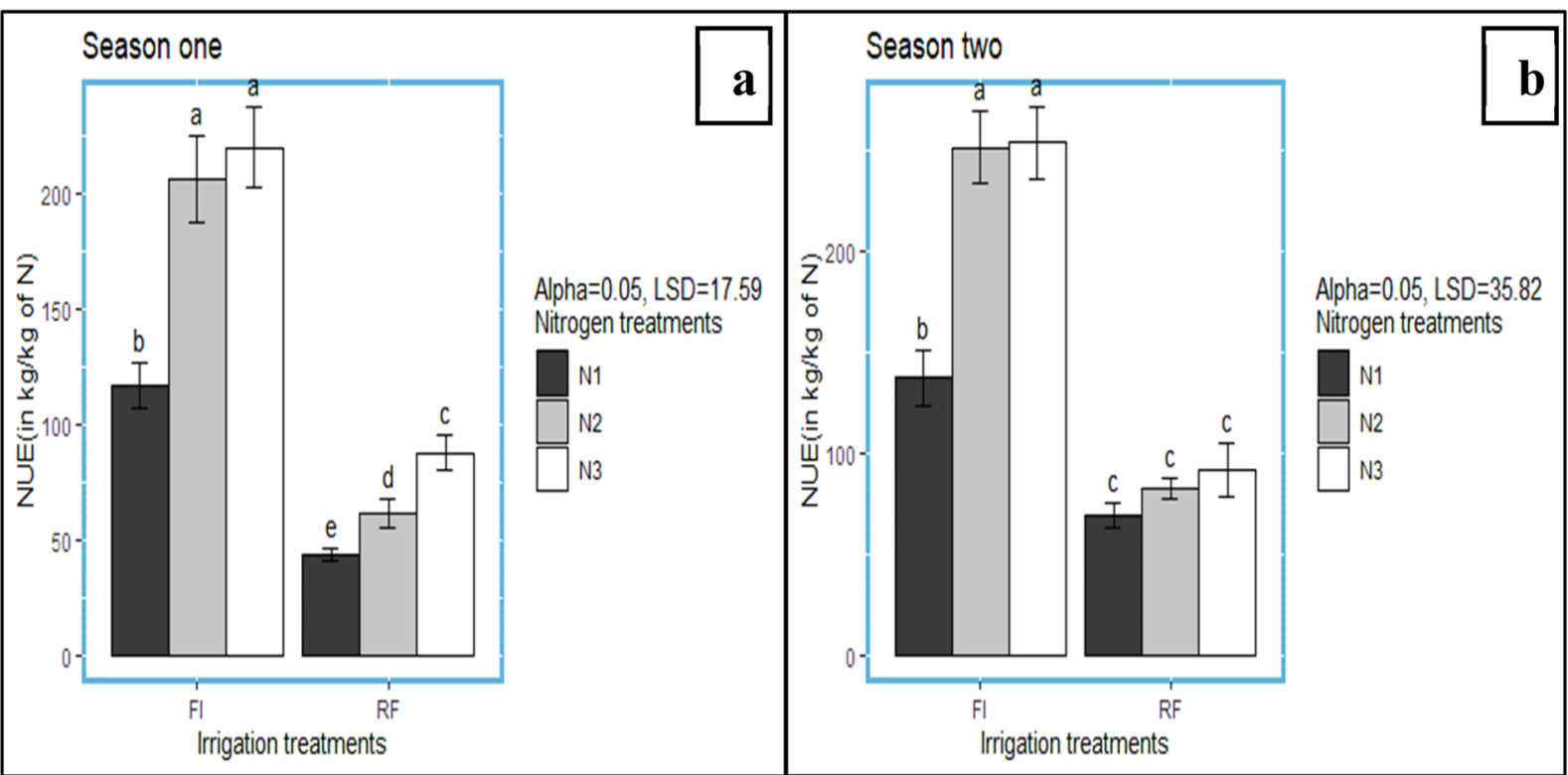

Fig. 5 Means separation of NUE of different growing seasons. Different letters indicate significant difference.

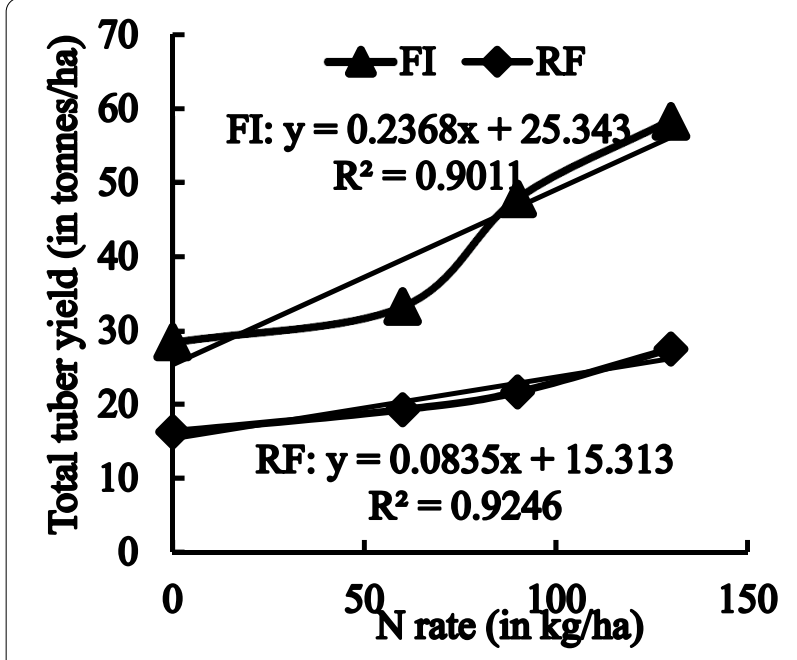

Fig. 6 Relationship between total tuber yield and N-rates under different irrigation treatments

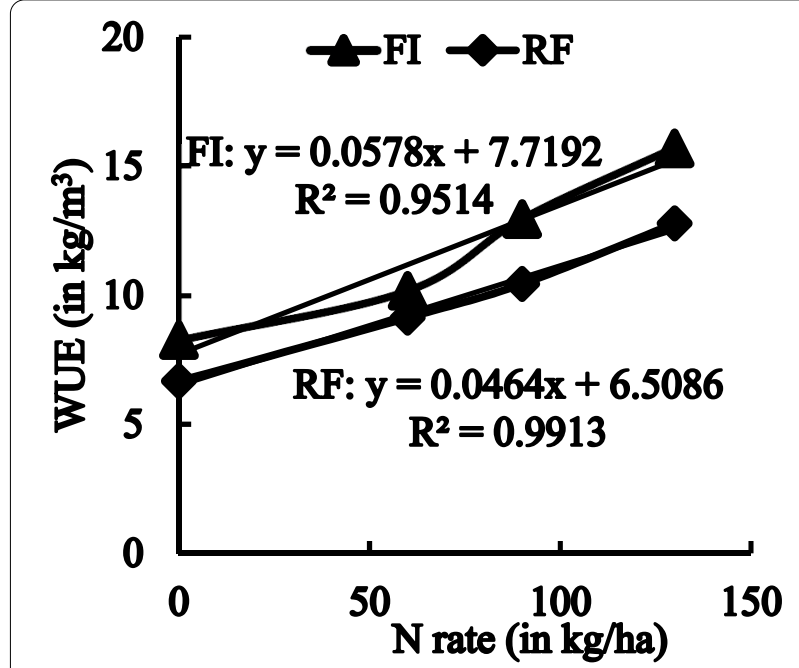

Fig. 7 Relationship between WUE and N-rates under different irrigation treatments

\section{Conclusion}

Yield components of potato were largely more responsive to the interaction effect of irrigation $\times \mathrm{N}$-fertilisation than a single effect of irrigation and $\mathrm{N}$-fertilisation. The highest total tuber yield and marketable were obtained under FI with an application of $130 \mathrm{~kg} \mathrm{~N} / \mathrm{ha}$. In this study, WUE was high when applying $130 \mathrm{~kg}$ N/ha. The NUE consistently increased with the increase in $\mathrm{N}$ rate up to 


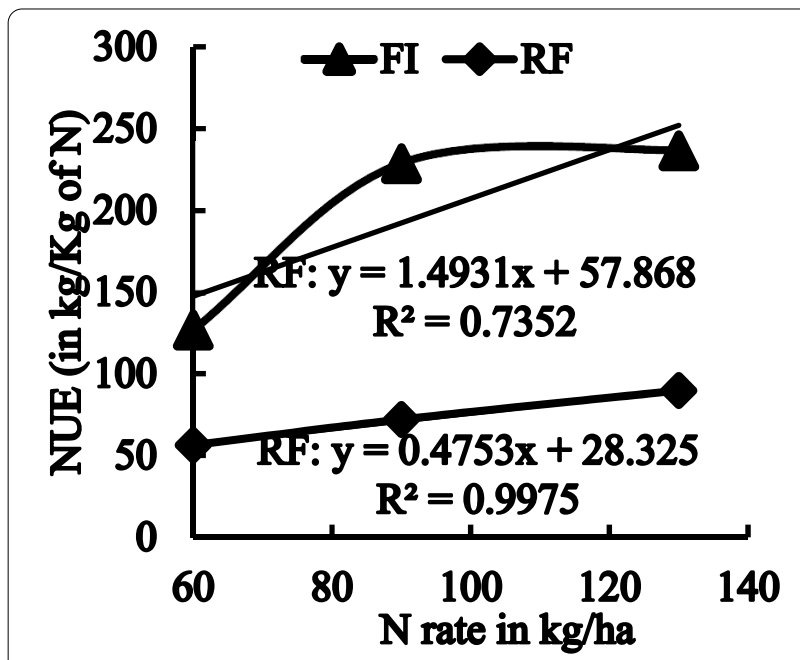

Fig. 8 Relationship between WUE and N-rates under different irrigation treatments

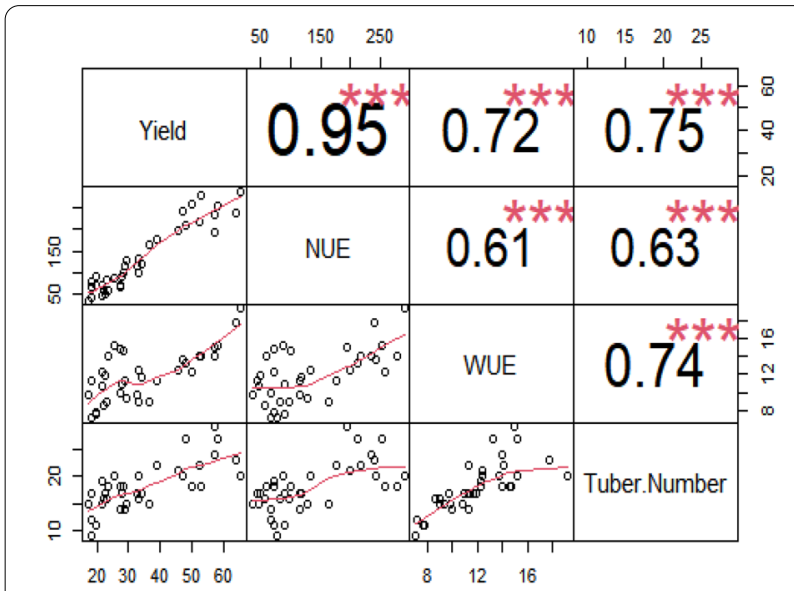

Fig. 9 Correlation between tuber number/plant, tuber yield, WUE and NUE

$90 \mathrm{~kg} / \mathrm{ha}$ in the two irrigation treatments. There was a high positive correlation between tuber number/plant, tuber yield, WUE and NUE. This study highlights the importance of introducing supplemental irrigation in the potato production area in Kenya. Farmers can achieve a high potato yield and marketable tuber yield in mollic Andosols when water deficits of the growing season are eliminated with supplemental irrigation and an application of $130 \mathrm{~kg} \mathrm{~N} / \mathrm{ha}$. This study also recommends further research on water regimes and irrigation methods that can lead to high potato yield with water-saving in mollic Andosols.

\section{Abbreviations}

NUE: Nitrogen use efficiency; HI: Harvest index; WUE: Water use efficiency; IWUE: Irrigation water use efficiency; FI: Full irrigation; RF: Rain-fed; KALRO: Kenya Agricultural and Livestock Research Organization.

\section{Acknowledgements}

The authors acknowledged the support of MasterCard Foundation at Regional Universities Forum for Capacity Building in Agriculture (MCF@RUFORUM) through its Transforming African Agricultural Universities to Meaningfully Contribute to Africa's Growth \& Development (TAGDev) program. The authors also thanked Prof. Paul K. Kimurto and Prof. Anthony Kibe for their support, advice and suggestions during the fieldwork. The authors also praised the contribution of the various anonymous reviewers whose suggestions contributed to the improvement of this work. Authors are also indebted to Emily Draru for her help during fieldwork.

\section{Authors' contributions}

FS contributed to the proposal writing, experiment design, fieldwork, data collection, data analysis and interpretation using (R software version 3.6.3) and writing the manuscript. Seth F.O. Owido and Dr. Joyce J. Lelei are my supervisors. They assisted in the proposal writing, experiment design fieldwork, data collection, data analysis and interpretation using ( $R$ software version 3.6.3) and writing the manuscript. All authors read and approved the final manuscript.

\section{Funding}

Not applicable to this manuscript.

\section{Availability of data and materials}

We declare that the data and materials used in this manuscript can be made available as per the editorial policy of the journal.

\section{Declarations}

Ethics approval and consent to participate

Not applicable to this manuscript.

\section{Consent for publication}

Not applicable to this manuscript.

\section{Competing interests}

The authors declared that there is no competing interest.

Received: 20 April 2021 Accepted: 21 July 2021

Published online: 18 August 2021

\section{References}

Abu El-Fotoh HM, Abd-El-Kader A, Mansour FY (2019) Effect of irrigation intervals, antitranspirants, compost and humic acid on growth and yield of sweet potato. Zagazig J Agric Res 46(3):649-664

Adavi Z, Moradi R, Saeidnejad AH, Tadayon MR, Mansouri H (2018) Assessment of potato response to climate change and adaptation strategies. Sci Hortic 228:91-102

Afzaal H, Farooque AA, Abbas F, Acharya B, Esau T (2020) Precision irrigation strategies for sustainable water budgeting of potato crop in Prince Edward Island. Sustainability 12(6):2419

Ahmadi SH, Andersen MN, Plauborg F, Poulsen RT, Jensen CR, Sepaskhah AR, Hansen S (2010) Effects of irrigation strategies and soils on field grown potatoes: yield and water productivity. Agric Water Manag 97(11):1923-1930

Allen RG, Pereira LS, Raes D, Smith M (1998) Crop evapotranspiration—Guidelines for computing crop water requirements-FAO Irrigation and drainage paper 56. Fao, Rome, 300(9): D05109

Anderson J, Ingram J (1993) A handbook of methods. CAB International, Wallingford, Oxfordshire, p 221 
Aschonitis V, Antonopoulos V, Lekakis E, Litskas V, Kotsopoulos S, Karamouzis D (2013) Estimation of field capacity for aggregated soils using changes of the water retention curve under the effects of compaction. Eur J Soil Sci 64(5):688-698

Ati AS, Shihab RM, Aziz SA, Ahmed FH (2010) Production and water use of potato under regulated deficit irrigation treatments. Ann Agric Sci (cairo) 55(1):123-128

Ati AS, lyada AD, Najim SM (2012) Water use efficiency of potato (Solanum tuberosum L.) under different irrigation methods and potassium fertilizer rates. Ann Agric Sci 57(2):99-103

Badr M, El-Tohamy W, Zaghloul A (2012) Yield and water use efficiency of potato grown under different irrigation and nitrogen levels in an arid region. Agric Water Manag 110:9-15

Bakar ZA, Mohemad R, Ahmad A, Deris MM (2006) A comparative study for outlier detection techniques in data mining. In: Paper presented at the 2006 IEEE conference on cybernetics and intelligent systems

Banerjee H, Ray K, Sarkar S, Puste A, Mozumder M, Rana L (2015) Impact of nitrogen nutrition on productivity and nutrient use efficiency of potato (Solanum tuberosum L.) in an inceptisol of West Bengal, India. SAARC J Agric 13(2):141-150

Bauder TA, Waskom R, Sutherland P, Davis J (2011) Irrigation water quality criteria. Colorado State University, Libraries

Begum M, Saikia M, Sarmah A, Ojah NJ, Deka P, Dutta PK, Ojah I (2018) Water management for higher potato production: a review. Int J Curr Microbiol App Sci 7(5):24-33

Blake G (1965) Bulk density. In: Black CA et al. (eds) Methods of soil analysis. Part 1. Agron. Monogr. 9. ASA, Madison, WI. Bulk density. Methods of soil analysis. Part 1. 1st edn. p. 374-390. Agron. Monogr. 9. ASA, Madison, WI, USA

Bouyoucos GJ (1962) Hydrometer method improved for making particle size analyses of soils 1. Agron J 54(5):464-465

Bryan E, Ringler C, Okoba B, Roncoli C, Silvestri S, Herrero M (2013) Adapting agriculture to climate change in Kenya: household strategies and determinants. J Environ Manage 114:26-35

Darabad GR (2014) Determining effects of irrigation stress on growth and yield of potato cultivars in Ardabil cold region. J Biodivers Environ Sci (JBES) 4:318-326

Djaman K, Irmak S, Koudahe K, Allen S (2021) Irrigation management in potato (Solanum tuberosum L.) production: a review. sustainability 13:1504. (MDPI stays neutral with regard to jurisdictional claims in published)

Erdem T, Erdem Y, Orta H, Okursoy H (2006) Water-yield relationships of potato under different irrigation methods and regimens. Sci Agricola 63(3):226-231

FAOSTAT (2020) Food and Agriculture Organization of the United Nations. Statistical database. Rome

Farrag K, Abdrabbo MA, Hegab SA (2016) Growth and productivity of potato under different irrigation levels and mulch types in the North West of the Nile Delta, Egypt. Middle East J Appl Sci 6(04):774-786

Godebo DD, Belay BDAST (2020) Effect of nitrogen fertilizer (urea) rate application on growth performance of potato (Solanum Tuberosum L.) on Vertisols of Central Highland of North Shewa, Ethiopia

lerna A, Mauromicale G (2018) Potato growth, yield and water productivity response to different irrigation and fertilization regimes. Agric Water Manag 201:21-26

Jaetzold R, Schmidt H, Hornetz B, Shisanya C (2007) Farm management handbook. Vol II, Part C, East Kenya. Subpart C, 1

Jensen ME, Allen RG. (2016). Evaporation, evapotranspiration, and irrigation water requirements. Task Committee on Revision of Manual 70.

Kimathi SM, Ayuya Ol, Mutai B (2021) Adoption of climate-resilient potato varieties under partial population exposure and its determinants: case of smallholder farmers in Meru County, Kenya. Cogent Food Agric 7(1):1860185

Koch M, Naumann M, Pawelzik E, Gransee A, Thiel H (2020) The importance of nutrient management for potato production part I: plant nutrition and yield. Potato Res 63(1):97-119

Leal Filho W, Esilaba AO, Rao KP, Sridhar G (2015) Adapting African agriculture to climate change. Springer

Li W, Xiong B, Wang S, Deng X, Yin L, Li H (2016) Regulation effects of water and nitrogen on the source-sink relationship in potato during the tuber bulking stage. PLOS ONE 11(1):e0146877
Mattar MA, El-Abedin TKZ, Al-Ghobari HM, Alazba A, Elansary HO (2021) Effects of different surface and subsurface drip irrigation levels on growth traits, tuber yield, and irrigation water use efficiency of potato crop. Irrigat Sci $1-17$

Mburu H, Cortada L, Haukeland S, Ronno W, Nyongesa M, Kinyua Z, Bargul JL, Coyne D (2020) Potato cyst nematodes: a new threat to potato production in East Africa. Front Plant Sci 11:670

McEwan M, Spielman D, Okello J, Hareau G, Bartle B, Mbiri D, Atieno E, Omondi B, Assfaw T, Gonzalez L (2021) Exploring the regulatory space for improving availability, access and quality of vegetatively propagated crop seed: potato in Kenya

McMurtrie RE, Näsholm T (2018) Quantifying the contribution of mass flow to nitrogen acquisition by an individual plant root. New Phytol 218(1):119-130

Meligy MM, Abou-Hadid A, El-Shinawy MZ, El-Behairy U (2020) Impact of climate change on water requirements and the productivity on potato crop. Egypt J Hortic 47(1):57-68

Metwaly E, El-Shatoury R (2017) Impact of foliar application with salicylic acid on growth and yield of potato (Solanum tuberosum L.) under different irrigation water quantity. J Plant Prod 8(10):969-977

Motsara M, Roy RN (2008) Guide to laboratory establishment for plant nutrient analysis food and agriculture organization of the united nations Rome vol. 19

Muthoni J, Nyamongo DN, Mbiyu M (2017) Climatic change, its likely impact on potato (Solanum tuberosum L.) production in Kenya and plausible coping measures. Int J Hortic 7

Muthoni J, Shimelis H, Mbiri D, Elmar S-G (2021) Assessment of national performance trials of potatoes in mid-altitude regions of Kenya. J Agric Crops 7(1):7-13

Nowacki W (2018) Water in potato production, problems and challenges. Ecolog Eng Environ Technol 19(6):14-25

Okalebo JR, Gathua KW, Woomer PL (2002) Laboratory methods of soil and plant analysis: a working manual second edition. Sacred Africa, Nairobi, 21

Ospina C, van Bueren EL, Allefs J, Bv E, Van der Putten P, Van der Linden C, Struik P (2014) Diversity of crop development traits and nitrogen use efficiency among potato cultivars grown under contrasting nitrogen regimes. Euphytica 199(1):13-29

Paredes P, D’Agostino D, Assif M, Todorovic M, Pereira LS (2018) Assessing potato transpiration, yield and water productivity under various water regimes and planting dates using the FAO dual Kc approach. Agric Water Manag 195:11-24

Ruttanaprasert R, Jogloy S, Vorasoot N, Kesmala T, Kanwar RS, Holbrook CC, Patanothai A (2016) Effects of water stress on total biomass, tuber yield, harvest index and water use efficiency in Jerusalem artichoke. Agric Water Manag 166:130-138

Salter PJ, Goode JE (1967) Crop responses to water at different stages of growth. Crop responses to water at different stages of growth

Sasani G, Patel CK, Patel R, Patel N, Patel S (2006) Efficient use of water and fertilizers through drip fertigation in potato. Potato J 33(3-4)

Satognon F, Lelei JJ, Owido SF (2021) Use of GreenSeeker and CM-100 as manual tools for nitrogen management and yield prediction in irrigated potato (Solanum tuberosum) production. Arch Agric Environ Sci $6(2): 121-128$

Scherer TF, Seelig B, Franzen D (1996) Soil, water and plant characteristics important to irrigation

Sebnie W, Esubalew T, Mengesha M (2021) Response of potato (Solanum tuberosum L.) to nitrogen and phosphorus fertilizers at Sekota and Lasta districts of Eastern Amhara Ethiopia. Environ Syst Res 10(1):1-8

Setu H, Mitiku T (2020) Response of potato to nitrogen and phosphorus fertilizers at Assosa, western Ethiopia. Agron J 112(2):1227-1237

Shunka E, Chindi A, Gebremedhin WG, Seid E, Tessema L (2017) Determination of optimum nitrogen and potassium levels for potato production in central high lands of Ethiopia. Open Agric 2(1):189-194

Smethurst P (2004) Tree physiology|nutritional physiology of trees. In: Burley $J$ (ed) Encyclopedia of forest sciences, edn. Elsevier, Oxford, pp 1616-1622

Sobhani AR, Hamidi H (2015) Effects of water stress and different potassium levels on yield, water use efficiency and harvest index in potato. 7(1):99-112 
Steele DD, Scherer TF, Prunty LD, Stegman EC (1997) Water balance irrigation scheduling: Comparing crop curve accuracies and determiningthe frequency of corrections to soil moisture estiates. Applied Engineering in Agriculture 13(5):593-599

Taiy RJ, Onyango C, Nkurumwa A (2017) Climate change challenges and knowledge gaps in smallholder potato production: the case of Mauche Ward in Nakuru County, Kenya. Int J Agric Sci Res (IJASR) 7(4):719-730

Tang J, Wang J, Fang Q, Wang E, Yin H, Pan X (2018) Optimizing planting date and supplemental irrigation for potato across the agro-pastoral ecotone in North China. Eur J Agron 98:82-94

Tolessa ES (2019) A review on water and nitrogen use efficiency of potato (Solanum tuberosum L.) inrelation to its yield and yield components. Arch Agric Environ Sci 4(2):119-132

Tolessa ES, Belew D, Debela A (2017) Effect of nitrogen rates and irrigation regimes on nitrogen use efficiency of potato (Solanum tuberosum $\mathrm{L}$.) in southwest Ethiopia. Science 2(3):170-175

Waaswa A, Oywaya NA, Mwangi Kibe A, Ngeno KJ (2021) Climate-smart agriculture and potato production in Kenya: review of the determinants of practice. Clim Develop 1-16
Waaswa A, Satognon F (2020) Development and the environment: Overview of the development planning process in the agricultural sector, in Uganda.Int J Sustain Dev 13(6):1

Waqas MS, Cheema MJM, Hussain S, Ullah MK, lqbal MM (2021) Delayed irrigation: an approach to enhance crop water productivity and to investigate its effects on potato yield and growth parameters. Agric Water Manage 245:106576

Wilcox L (1955) Classification and use of irrigation waters US Department of Agriculture

Zhang Y-L, Wang F-X, Shock CC, Yang K-J, Kang S-Z, Qin J-T, Li S-E (2017) Effects of plastic mulch on the radiative and thermal conditions and potato growth under drip irrigation in arid Northwest China. Soil Tillage Res $172: 1-11$

\section{Publisher's Note}

Springer Nature remains neutral with regard to jurisdictional claims in published maps and institutional affiliations.

\section{Submit your manuscript to a SpringerOpen ${ }^{\odot}$ journal and benefit from:}

- Convenient online submission

- Rigorous peer review

- Open access: articles freely available online

- High visibility within the field

- Retaining the copyright to your article

Submit your next manuscript at $\boldsymbol{\nabla}$ springeropen.com 